\title{
Family Planning and Marital Satisfaction among Married People in South West Nigeria. A Case Study of Lagos State
}

\author{
Alade Folasade Adesola \\ Institute of Education, Faculty of Education, \\ Ekiti State University, Ado-Ekiti, \\ Nigeria.
}

\begin{abstract}
Family planning helps married men and women in a number of ways. It has given them the opportunity to avoid unwanted pregnancies, choose the number and spacing of their children and enjoy sexual intimacy which could lead to marital satisfaction. This study therefore examined the relationship between family planning and marital satisfaction among married people in Lagos State. Descriptive research design of the survey type was adopted. A questionnaire titled "perception of family planning among married people was used. This was designed by the researcher and validated by experts in the field of psychology. A reliability co-efficient of 0.77 was obtained. The population consisted of all literate married people in Lagos State while the sample comprised of five hundred and nineteen subjects selected through stratified random sampling. One research question was raised and one hypothesis generated to guide the study. This was tested at a 0.05 level of significance. The result of the analysis showed a favourable perception to family planning, also, a significant relationship was established between family planning and marital satisfaction. It was therefore recommended that married people should have more access to safe and voluntary family planning counselling and services for better enhancement of marital satisfaction.
\end{abstract}

Keywords: Family planning, married people, marital satisfaction.

\section{Introduction}

The family is the most important primary group and the smallest social unit in the society. It is universal in the sense that no human society could exist without some form of family organisation. Family is also a group defined by a sex relationship which provides the procreating and up-bringing of children. However, procreating and up-bringing are not visible without a union between a man and woman.

Marriage, according to Yahaya, Esere, Ogunsanmi and Oniye, is an institution oriented towards fostering the coming together of two individuals with their personality traits as husband and wife to plan for their future and set up their own home [11]. Marriage thus exists as an avenue for couples to meet the satisfaction of security and of enduring affection and companionship.

Marriage to Girgis, George and Anderson is distinguished from every other form of friendship inasmuch as it is comprehensive [4]. It involves a sharing of lives and resources; and a union of minds and wills - hence, among other things, the requirement of consent for forming a marriage. According to them, on the conjugal view, it also includes organic bodily union.

It has been observed that when a spouse is happy with the relationship aspect of marriage, he or she tends to be happy and this could lead to marital satisfaction. Marital satisfaction is viewed in a number of ways by various researchers. According to Stone and Schackelford, marital satisfaction is a mental state that reflects the perceived benefits and costs of marriage to a particular person [9]. The more costs a marriage partner inflicts on a person, the less satisfied one generally is with the marriage and with the marriage partner. Similarly, the greater the perceived benefits are, the more satisfied one is with the marriage and with the marriage partner.

Carroll sees marital satisfaction for men to be related to the frequency of pleasurable activities (doing things together) in the relationship, while for women, it was related to the frequency of pleasurable activities that focus on emotional closeness [2]. Other important variables according to her including being able to talk to each other and self-disclose, physical and emotional intimacy and personality similarities are all instrumental in achieving greater relationship quality. Also, John Cottman, a relationship expert, has found that the quality of the friendship with one's spouse is the most important factor in marital satisfaction for both men and women [3].

One of the pleasurable activities and the quality of the friendship with one's spouse could be sexual relationship which could lead to marital satisfaction. According to Leman, sex life colours marriage from top to bottom and it is the most powerful marital glue a couple can have [5]. He is of the opinion that a sexually fulfilled man will normally be a better father and a better employee and a sexually fulfilled woman will have less stress and more joy in her life. However, 
sexual pleasure cannot be fulfilled without the use of family planning among married couples.

Family planning to Page, is the means of controlling, if, when and how many children to have [7]. Through family planning, couples and individuals may take decisions, based on health and economics that are best for them and their families. Osakinle believed that family planning usually helps women to prevent unwanted pregnancies and sexually transmitted infections [6]. In her submission, she opined that family planning can help women of higher age to enjoy sex without any risk of becoming pregnant.

Family planning helps the couple to avoid unwanted children, to regulate the intervals between pregnancies and to determine the number of children in the family. Ringheim and Gribble noted that contraception helps individual to choose when to have children, prevents unintended pregnancies, averts maternal and child deaths and also prevents abortions [8]. In the same vein, World Health Organisation also noted that family planning can help women wait at least, two years before trying to become pregnant again, thereby reducing newborn, infant and child deaths significantly [10].

From all indications, it has been revealed that marriage involves the coming together of two individuals, especially a man and a woman to raise a family and to engage in sexual intimacy. It has also been observed that lack of sexual intimacy could cause tension and problems within the family which can lead to serious marital disharmony. Adesanya observed that when marital partners fail to satisfy each other in a sexual encounter over a long period, problems ensure [1]. Therefore, to enjoy sex in a marriage, family planning methods have to be put in place to ensure marital satisfaction.

The trust of this paper is to find out the relationship between family planning and marital satisfaction among married people in South West Nigeria. To determine this, one research question was raised and one null hypothesis generated to guide the study.

\section{Research Question}

What is the perception of married people in Lagos State to family planning?

\subsection{Research Hypothesis}

There is no significant relationship in the perception of family planning and marital satisfaction among married people in Lagos State.

\section{Methodology}

The study was a descriptive research of the survey type. The population for the study consisted of all married people in Lagos State at the time of the research. A sample of six hundred subjects consisting of male and female married people was selected through stratified sampling technique in five Local Government Areas of Lagos State. The subjects comprised of married people from mosques, churches, hospitals, local government offices and schools. The selected local governments covered the two provinces in Lagos State, that is, Lagos Island and Lagos Mainland.

\section{Research Instrument}

The instrument used was questionnaire designed by the researcher. It was made up of two sections, A \& B. In section A, eight items were designed to seek information from the subjects about their personal data while section B contained forty items generated from extensive literature review. It was validated by experts in the field of psychology and counselling. Its reliability was ensured through test re-test method using Pearson Product Moment Correlation for analysis. This was carried out in Ekiti State at the interval of two weeks. A reliability co-efficient of 0.77 was obtained and this was considered adequate and reliable for the study.

The instrument was administered by the researcher and some trained assistants. Five hundred and nineteen copies of questionnaire were returned for analysis at the end of the exercise.

\section{Results}

\subsection{Descriptive Analysis}

\section{Research Question}

What is the perception of married people in Lagos State to family planning?

Table I: Perception of married people to family planning.

\begin{tabular}{|l|c|c|}
\hline & Favourable & Unfavourable \\
\hline $\begin{array}{l}\text { Perception } \\
\text { of married } \\
\text { people }\end{array}$ & $314(60.5 \%)$ & $205(39.5 \%)$ \\
\hline
\end{tabular}

$$
\mathrm{N}=519
$$

Table I shows $60.5 \%$ of the respondents are favourably disposed to family planning while 39.5 have unfavourable perception towards it.

\subsection{Research Hypothesis}

There is no significant relationship in the perception of family planning and marital satisfaction among married people in Lagos State. 
Table 2: Relationship between family planning and marital satisfaction among married people in Lagos State.

\begin{tabular}{|l|c|c|c|c|}
\hline \multicolumn{1}{|c|}{ Variable } & $\mathbf{N}$ & mean & rc & rt \\
\cline { 1 - 3 } $\begin{array}{l}\text { Family } \\
\text { planning }\end{array}$ & 519 & 99.11 & $0.741^{*}$ & 0.195 \\
\cline { 1 - 3 } $\begin{array}{l}\text { Marital } \\
\text { satisfaction }\end{array}$ & 519 & 30.55 & & \\
\hline
\end{tabular}

*Significant, $\mathrm{P}>0.05$

The result in table 2 shows a significant relationship in the perception of family planning and marital satisfaction among married people because the calculated value which is 0.747 is greater than the table value of 0.195 . Therefore, the null hypothesis that says there is no significant relationship between family planning and marital satisfaction is rejected.

\section{Discussion of Findings}

The result of the descriptive analysis on the research question raised in this study revealed that majority of the respondents had a favourable opinion towards family planning. This could be due to positive value some researchers place on family planning. The finding is in line with that of Ringheim and Gribble who noted that contraception helps individual to choose when to have children, prevents unintended pregnancies averts maternal and child deaths and also prevent abortions [8]. It also corroborates that of Osakinle who believed family planning helps women to prevent unwanted pregnancies, limit the number of children which will bring healthy reproductive living and healthy sexual relationships among couples [6].

The finding of the hypothesis generated also established a significant relationship between family planning and marital satisfaction. This could be due to fact that lack of sexual intimacy could cause tension and problems within the family which can lead to serious marital disharmony, hence, the need for family planning. Carroll shed more light on this [2]. She sees marital satisfaction for men to be related to the frequency of pleasurable activities in a relationship, while for women, it was related to pleasurable activities that focus on emotional closeness. This could be in form of sexual relationship no wonder Adesanya observed that when marital partners fail to satisfy each other in a sexual encounter over a long period, problems ensure [1].

\section{Conclusion}

Based on the findings of this study, it could be deduced that majority of married people in Lagos State had favourable perception towards family planning. There is also a relationship between family planning and marital satisfaction. One could therefore conclude that family planning is a booster to sexual intimacy which could lead to marital satisfaction among couples.

\section{Recommendations}

Based on the findings of this study, it was recommended that family planning services should be provided in all walks of life, especially for married people. This will encourage people with unfavourable perception the more. Also, since there is a relationship between family planning and marital satisfaction, it is recommended that married people should have access to safe and voluntary family planning counselling and services which could expose them to importance of family planning.

\section{References}

[1] Adesanya, S.A.: Correlates of marital stability among couples in South Western Nigeria. Unpublished Ph.D thesis, University of Ado-Ekiti.

[2] Corroll, J.L.: Sexuality now. United States of America.

[3] Cottman, J. \& Silver, N.: The seven principles for making marriage work. New York. Crown Publishers.

[4] Girgis, S. George R.P. \& Anderson, R.T.: What is marriage? Harvard journal of law and public policy. Vol. 34,1 (1). $245-287$.

[5] Leman, K.: How important is sex in marriage. Electronic journal of human sexuality. Retrieved, May, 2005.

[6] Osakinle, E.O.: Family planning practices among secondary school women teachers in Ekiti State. International Journal or Research in Counselling and Sports Sciences 1, (1) 63 - 67.

[7] Page, A.: Concept of family planning. eHow.com mobile. Retrieved 06/08/2014

[8] Ringher, K. and Gribble, J.: Population Reference Bureau. Washington D.C. USA

[9] Stone, E.A. \& Shackelford, T.K.: Encyclopaedia of social psychology. SAGE Publications. INC.

[10] WHO: Unsafe Abortion - Global and regional estimates of the incidence of unsafe abortion and associated mortality in $2003,5^{\text {th }}$ ed.

[11] Yahaya, L.A; Osere, M.O; Ogunsanmi, J.O. \& Oniye, A.O.: Marriage, sex and family counselling. Unilorin Press. 